This is the Author's Accepted Manuscript (AAM). Please cite this article as follows:

Gonçalves, F.M.R.R., Cândido, C.J.F., and Feliciano, I.M.P.L. (2020). Inertia, group conformity and patient loyalty in healthcare in the information age. Journal of Service Theory and Practice, 30(3), 307-330.

DOI : http://dx.doi.org/10.1108/JSTP-08-2019-0184 HTML: http://www.emeraldinsight.com/doi/10.1108/JSTP-08-2019-0184

This article is $\odot$ Emerald Group Publishing and permission has been granted for this version to appear here (https://sapientia.ualg.pt). Emerald does not grant permission for this article to be further copied/distributed or hosted elsewhere without the express permission from Emerald Group Publishing Limited.

\title{
Inertia, group conformity and patient loyalty in healthcare in the information age
}

\begin{abstract}
Purpose. To analyse the influence of inertia and group conformity on loyalty in healthcare.

Methodology. Structural equation model developed from the literature and tested with crosssectional data from a patient online survey.

Findings. Inertia is a significant antecedent of loyalty and has a stronger effect in healthcare than in other service sectors. Group conformity has no significant effect in healthcare.

Research Implications. The strength of the impact of inertia [group conformity] on loyalty depends on the importance of the customer need that the service industry satisfies, in Maslow's hierarchy of needs. Where inertia (stability need) is equally or more [less] important than the customer need, the influence of inertia on loyalty should be positive and strong [weak or insignificant]. In services that satisfy needs more [equally or less] important than group conformity (belonging need), there may be an insignificant [significant] influence of group conformity on customer loyalty, even [especially] in credence services.

Practical Implications. Healthcare providers can exploit the stronger effect of inertia in healthcare through development of inertia-based loyalty policies. Regulatory authorities should be vigilant to ensure that these policies are not detrimental to patients. 'Inert' patients must become responsible for assessing their loyalties. Authorities and reference groups must stimulate customer loyalty assessments, and assist by providing impartial information.

Originality. This is the first study to address the influence of inertia and group conformity on loyalty in the healthcare sector and, from the perspective of Maslow's hierarchy of needs, it is the first to do so in any service sector.
\end{abstract}

Keywords: apathy, habit, online communities, perceived price, repurchase, customer retention, satisfaction, service quality, social influence. 


\section{Introduction}

Inertia is an individual's apathetic state that contributes to maintaining that individual's habits and routines and to preventing behavioural change (Genschel, 1997; Chatterjee, 1998; Wu, 2011a; Li, 2015; Lucia-Palacios et al., 2016). Inertia prevents individuals from looking for alternative service providers and from changing consumption behaviours (Wu, 2011a; LuciaPalacios et al., 2016; Gray et al., 2017). In healthcare, in the absence of a strong stimulus, such as clear negative feedback about a current provider, the patient may prefer to avoid change and, consequently, remain loyal to a healthcare organisation.

Group conformity is, in turn, a social influence through which individuals replicate the attitudes and behaviours of a reference group or group leader (Hornsey and Jetten, 2005; Nitzan and Libai, 2011; Gu et al., 2016). Similarly to inertia, group conformity can determine, to a certain extent, customer buying behaviours (Tsai and Pai, 2012; Gu et al., 2016; Toker-Yildiz, 2017), and loyalty to a healthcare provider.

Both inertia and conformity can be influenced by strong opinions circulating on the internet or other media, and can influence patient loyalty. The internet, published materials, social and other media raise awareness, urge people to change, create models/ideals of health and fitness, and influence patient opinions, needs and choices. In particular, the internet and other media can affect patient inertia in changing healthcare providers, create group conformity behaviours to mimic new trends, and affect patient loyalty.

The advent and omnipresence of the internet and other media makes the relationships between group conformity, inertia and patient loyalty an interesting research topic and contributes to raising the research question of how strong the influence of these variables is on loyalty. More specifically, it contributes to raising the two research questions addressed in this study: (1) how does inertia influence loyalty in healthcare, and, (2) how does group conformity influence loyalty in healthcare.

Previous research on the impact of inertia on service customer loyalty is scarce (Wu, 2011a; Kim and Kang, 2016; Gray et al., 2017). Similarly, research on the influence of group conformity on service customer loyalty is also scant (Ruiz-Mafe et al., 2016; Saleem et al., 2016; Toker-Yildiz et al., 2017). Besides this scarcity, the research on these topics in the healthcare management area is completely non-existent. As far as the authors are aware, no research in the specific context of healthcare has addressed the impact of inertia or conformity on loyalty.

The study of inertia and conformity as antecedents to loyalty is important in the context of healthcare because health is a major priority need for human beings. Alongside the importance of healthcare, stability (inertia) and belonging (group conformity) are similarly important needs to human beings (Maslow, 1970; Tsai et al., 2017). Specifically, health and inertia are on the second most important level of human needs (safety/stability), whereas group conformity is on the third most important level (love/belonging). Given that humans attribute priority to the satisfaction of some needs over others, it is important to understand how patients relate and prioritise health, inertia and group conformity. Consequently, this paper aims to identify factors that influence patient loyalty in healthcare, in the context of the information economy, and to study the influence of inertia and conformity on loyalty.

Maslow's (1970) hierarchy of human needs adds novelty to the study because it has not been considered in previous works. In fact, this research is the first to study the influence of inertia and group conformity on customer loyalty from the perspective of Maslow's (1970) theory of human motivation. Alongside helping to develop the main research hypotheses of this study, Maslow's hierarchy of needs allows a comparison of the strength of the relationships between inertia, conformity and loyalty across industries, which has not been made to date. This comparison across service industries, which satisfy needs at different levels of Maslow's (1970) hierarchy, suggests significant research implications for the healthcare and for other 
service industries. Specifically, this study discovers that the strength of the impact of inertia [group conformity] on loyalty depends on the importance of the customer need that the service industry satisfies. Where inertia is equally or more [less] important than the customer need, the influence of inertia on loyalty is positive and strong [weak or insignificant]. In services that satisfy needs more [equally or less] important than group conformity, there is an insignificant [significant] influence of group conformity on customer loyalty. From these theoretical implications, several practical implications are drawn for major healthcare stakeholders.

Besides the main research variables (inertia and conformity), this study considers the influence of three additional variables: price, quality and satisfaction. These variables have been researched as determinants to customer loyalty in both services and manufacturing industries, and studies have established them as significant antecedents to customer loyalty (Moliner, 2009; Lobo et al., 2014; Buell et al., 2016; Zhou et al., 2017). Moreover, the literature on loyalty, in the specific context of healthcare, has identified price, quality and satisfaction as key success factors (Zhou et al., 2017). Increasingly, patients make more careful choices regarding healthcare providers: insurance companies and regulatory agencies press healthcare providers for improved quality (Arbel and Greenberg, 2016); accreditation and standardisation certificates are less able to differentiate competitors (Marimon et al., 2009; Cândido et al., 2019), and patients are starting to look for affordable quality healthcare in foreign countries (Han and Hyun, 2015). Consequently, private hospitals that do not deliver service quality at reasonable prices, and do not satisfy their patients, risk losing patient loyalty and market share (Anbori et al., 2010). Consistent with these arguments, these variables are considered together with inertia and group conformity in this research.

The reminder of the article is organised as follows. Section 2 reviews the literature and develops the research hypothesis. Section 3 summarises the research methodology, with details on sample size, measurement tool and data analysis. Section 4 presents a description of the sample and the main empirical evidence. Sections 5 and 6 contain a theoretical discussion and draw out the research implications. Finally, Section 7 concludes the article and presents research limitations.

\section{Literature review and hypotheses}

This study addresses two research questions: how does inertia influence loyalty and how does conformity influence loyalty. In accordance with these research questions, this section reviews the literature on inertia, group conformity and loyalty, and subsequently reviews the related literature on price, quality and satisfaction. Research hypotheses are carefully developed, initially with the aid of the relevant literature on service management, and then with the aid of the literature on the healthcare sector, when available.

Inertia is a state of inactivity that inhibits creativity, innovative thinking and behaviour change (Chatterjee, 1998). Inertia is synonymous with apathy, habit, routine, and no changes (Genschel, 1997; Wu, 2011a; Li, 2015; Gray et al., 2017). Change requires a break with the past, abandoning old routines, habits, and shifting to new ways of thinking; conversely, inertia maintains the general state of things, the habit, the status quo. Likewise, in this paper, inertia is considered as an individual's apathetic state that maintains their habits and routines and can contribute to preventing behavioural change.

Consumer inertia key aspects are automaticity, lack of awareness and very little conscious deliberation (Liu-Thompkins and Tam, 2013; Olsen et al., 2013). The consumer buys from the same provider because it is convenient (Wu, 2011a), requires less effort (Gray et al., 2017), does not involve consideration of alternatives (Lucia-Palacios et al., 2016), avoids the stress and risks associated with switching providers (Liu-Thompkins and Tam, 2013; Kim and Kang, 2016) and prevents the need to learn new service routines and practices ( $\mathrm{Wu}, 2011 \mathrm{a}$; Kim and Kang, 2016). 
Although inertia has the potential to influence consumer behaviour, there is scarce management research addressing the impact of inertia on loyalty $(\mathrm{Wu}, 2011 \mathrm{a}$; Kim and Kang, 2016; Gray et al., 2017). According to a search conducted by the authors in the Web of Science database, only eight empirical studies have addressed the direct relationship between these variables in service industries. Table 1 is a summary of these studies with authors' names, research aims, methodologies, main conclusions, and other aspects. This table shows evidence of a significant relationship between inertia and loyalty, which varies from a not very strong influence (0.05) to a strong impact (0.335). The first study, Ranaweera and Neely (2003), found a small but insignificant relationship between inertia and customer retention. However, all other studies found a significant relationship in the expected direction, that is, the higher the inertia, the greater the level of customer loyalty, or the lower the likelihood of switching provider. In all of these studies, inertia has a positive and direct effect on loyalty. Gray et al. (2017) adds that the effect of inertia can last a significant length of time (the researchers conducted two surveys, 11 months apart from each other, and the inertia effects were still in place in the second survey). Lucia-Palacios et al. (2016) further emphasise that the omission of inertia from loyalty models can lead to biased results and, Liu-Thompkins and Tam (2013) concur, ignoring inertia can lead to negative consequences on consumer purchase behaviour, particularly if marketing strategies ignore the specific nature of inertia.

Table 1. Research on the direct effect of inertia on loyalty in service industries

\begin{tabular}{|c|c|c|c|c|c|}
\hline Study & Aim & Method & Industry & Main conclusion & Coefficient \\
\hline $\begin{array}{l}\text { Gray et al. } \\
(2017)\end{array}$ & $\begin{array}{l}\text { Investigate the extent to which } \\
\text { customer inertia influences brand } \\
\text { switching intent }\end{array}$ & PLS-SEM & $\begin{array}{l}\text { Cell phone } \\
\text { services }\end{array}$ & $\begin{array}{l}\text { Inertia has direct and } \\
\text { moderating effects on } \\
\text { switching intentions }\end{array}$ & $\begin{array}{c}0.08^{* *} \\
\text { (absolute } \\
\text { value) }\end{array}$ \\
\hline $\begin{array}{l}\text { Kim and } \\
\text { Kang } \\
(2016)\end{array}$ & $\begin{array}{l}\text { Clarify the effects of user loyalty } \\
\text { and nonconscious inertia on } \\
\text { continued use }\end{array}$ & PLS-SEM & $\begin{array}{l}\text { Mobile } \\
\text { communication } \\
\text { platform } \\
\text { services (e.g.: } \\
\text { WhatsApp) }\end{array}$ & $\begin{array}{l}\text { Inertia played a significant } \\
\text { role in establishing user } \\
\text { loyalty but no effect on } \\
\text { actual continued use }\end{array}$ & $0.258 * * *$ \\
\hline $\begin{array}{l}\text { Lucia- } \\
\text { Palacios et } \\
\text { al. }(2016)\end{array}$ & $\begin{array}{l}\text { Examine the effect of inertia on } \\
\text { the likelihood of switching to } \\
\text { cloud services }\end{array}$ & PLS-SEM & Cloud services & $\begin{array}{l}\text { Inertia is one of the main } \\
\text { reasons for not switching to } \\
\text { cloud services }\end{array}$ & $\begin{array}{c}0.254 * * \\
\text { (absolute } \\
\text { value) }\end{array}$ \\
\hline $\begin{array}{l}\text { Liu- } \\
\text { Thompkins } \\
\text { and Tam } \\
\text { (2013) }\end{array}$ & $\begin{array}{l}\text { Explore the impacts of attitudinal } \\
\text { loyalty and habit on behavioural } \\
\text { loyalty and purchase behaviour }\end{array}$ & $\begin{array}{l}\text { Hierarchical } \\
\text { regression }\end{array}$ & $\begin{array}{l}\text { Convenience } \\
\text { store retail }\end{array}$ & $\begin{array}{l}\text { Attitudinal loyalty and habit } \\
\text { influence repeat purchase } \\
\text { and ignoring inertia can lead } \\
\text { to negative consequences }\end{array}$ & $0.05 * * *$ \\
\hline $\begin{array}{l}\text { Lai et al. } \\
\text { (2011) }\end{array}$ & $\begin{array}{l}\text { Extend the customer retention } \\
\text { model with inertia, satisfaction } \\
\text { and switching costs }\end{array}$ & $\begin{array}{l}\text { OLS } \\
\text { Regression } \\
\text { analysis }\end{array}$ & $\begin{array}{l}\text { Auto insurance } \\
\text { service } \\
\text { (compulsory } \\
\text { insurance) }\end{array}$ & $\begin{array}{l}\text { The higher the inertia, the } \\
\text { greater the level of customer } \\
\text { retention }\end{array}$ & $0.335 * * *$ \\
\hline $\begin{array}{l}\mathrm{Wu} \\
(2011 \mathrm{a})\end{array}$ & $\begin{array}{l}\text { Develop a model of customer } \\
\text { loyalty including satisfaction and } \\
\text { inertia }\end{array}$ & $\begin{array}{l}\text { Hierarchical } \\
\text { regression } \\
\text { analysis }\end{array}$ & $\begin{array}{l}\text { Mobile } \\
\text { communication } \\
\text { services }\end{array}$ & $\begin{array}{l}\text { Positive effect of inertia on } \\
\text { customer loyalty }\end{array}$ & $0.131 * *$ \\
\hline $\begin{array}{l}\text { Lin and } \\
\text { Sun }(2009)\end{array}$ & $\begin{array}{l}\text { Explore the association of internet } \\
\text { customer satisfaction and loyalty } \\
\text { with specific holdup cost (habit) }\end{array}$ & CB-SEM & Internet retail & $\begin{array}{l}\text { Specific holdup cost (habit) } \\
\text { can positively influence e- } \\
\text { loyalty, but cannot positively } \\
\text { influence e-satisfaction }\end{array}$ & $0.15^{* * *}$ \\
\hline $\begin{array}{l}\text { Ranaweera } \\
\text { and Neely } \\
(2003)\end{array}$ & $\begin{array}{l}\text { Develop a model of customer } \\
\text { retention including inertia, price } \\
\text { perception, quality and } \\
\text { indifference }\end{array}$ & Correlation & $\begin{array}{l}\text { Phone } \\
\text { communication } \\
\text { services }\end{array}$ & $\begin{array}{l}\text { Absence of a linear } \\
\text { relationship between inertia } \\
\text { and customer retention does } \\
\text { not mean absence of a } \\
\text { nonlinear relationship }\end{array}$ & $0.038^{\text {n.s }}$. \\
\hline
\end{tabular}

Note: ${ }^{\text {.s. }}$ Not significant. $* *$ Significant at the 5 percent level. $* * *$ Significant at the 1 percent level.

Inertia can be beneficial for service providers. Organisations may create obstacles to prevent customer loss and brand renouncement, which makes customers 'inert' in the face of possible change and thus contribute to their loyalty (Lin and Sun, 2009; Pollack, 2017). The 
removal of these obstacles usually implies some cost, effort or discomfort for the customer and, because of that discomfort, the customer may prefer to remain with their current service provider (Lin and Sun, 2009; Wu, 2011a; Li, 2015; Pollack, 2017). Inertia has been seen as mostly irrational, because it is passive and non-conscious (Olsen et al., 2013), but it might as well be seen as efficient because inertia avoids active planning and the balancing of alternatives at each consumption decision (Olsen et al., 2013). Inertia can be positive for the consumer, because it saves effort but, over time, the deliberate ignorance of alternatives and blind loyalty to a service provider can become detrimental.

In summary, the management literature on the relationship between inertia and loyalty suggests that (1) there can be different degrees of inertia, and (2) inertia can have significant consequences for the consumer and for the service provider. Similarly, in this study, customer inertia is considered as a variable that can assume different degrees and that can affect customer loyalty: the higher the degree of inertia, the higher the resulting level of loyalty. In the healthcare literature, however, there are no studies addressing the relationship between inertia and loyalty. Consequently, besides the literature already reviewed, Maslow's (1970) theory of human motivation is here used to overcome the lack of research in healthcare and help to hypothesise a relationship between these variables.

According to Maslow, stability (inertia) and freedom from illness (health) are two human needs and part of the larger group of safety needs (level 2 of Maslow's pyramid): when an individual 'is taken ill [he] may ... develop fear, nightmares, and a need for protection and reassurance never seen in him before' (Maslow, 1970:40). Until such fears concerning health are relieved - and protection and reassurance are ensured - no progress can be made toward higher levels of the pyramid (Zalenski and Raspa, 2006). This indicates that, when their health is at stake, individuals also look for the protection and reassurance (safety and stability) that result from maintaining the same service provider (inertia). The patients may not wish to abdicate the feeling of safety and reassurance (Maslow, 1970) which results from being cared for by someone familiar. They may feel safe and reassured because they are being cared for by a professional or a healthcare organisation they already know. Consequently, the relationship between inertia and loyalty might be even stronger in healthcare than in other service sectors, because inertia (stability) and health are both needs at a very important level of the Maslow (1970) pyramid. Thus, the first hypothesis is:

H1: Patient inertia positively affects patient loyalty.

Individuals identify with social groups (Lee et al., 2010; Tsai and Pai, 2012). This identification involves self-categorisation, which occurs through a person's comparison of their own defining characteristics (beliefs, education, occupation, preferences...) and those of the group (Lee et al., 2010; Tsai and Pai, 2012). Identification involves also affective commitment, which makes the identification with the reference group stronger, because of feelings of attachment and belonging to the group (Tsai and Pai, 2012). People accept the influence of groups (Ruiz-Mafe, 2016) whose characteristics they share and for whom they feel something (Nitzan and Libai, 2011). This social influence can shape an individual's awareness, opinions and attitudes (Saleem et al., 2016). The shaping of opinions occurs through information sharing with members of the group in private communications, public communications or mass media (Nitzan and Libai, 2011; Ruiz-Mafe et al., 2016). The internet and online communities are a new means to interact (Tsai and Pai, 2012), which amplifies the social influence of reference groups. Internet and other media can quickly take the group's views to members and affect their perceptions, attitudes and behaviours (Lucia-Palacios et al. 2016). Through communication, reference groups exert an influence that contributes to align the group members' behaviours with the norms and standards that the group considers appropriate ( $\mathrm{Gu}$ et al., 2016). More generally, social interaction with reference groups can influence the adoption of new behaviours by individuals, the continuance of current behaviours and the ending of old behaviours (Nitzan 
and Libai, 2011). Group conformity can be defined as a social influence through which individuals replicate the beliefs, attitudes and behaviours of a reference group (Hornsey and Jetten, 2005).

Although group conformity has the potential to influence consumer behaviour, little management research has addressed the impact of conformity on customer loyalty (Nitzan and Libai, 2011; Saleem et al., 2016; Toker-Yildiz et al., 2017). According to a search in the Web of Science database, only eight empirical studies have addressed the direct relationship between these variables in service industries. Table 2 is a summary of these studies, indicating authors' names, research aims, methodologies, main conclusions, and other aspects. This table shows evidence of a significant relationship between group conformity and loyalty. Only one of the studies, Saleem et al. (2016), found an insignificant relationship between conformity and customer retention. All other studies found significant relationships, which varies from a small/medium influence (0.181) to a strong impact (0.586). All of these significant relationships are in the expected direction, that is, the higher the group conformity/social influence, the greater the level of customer loyalty, or the lower the likelihood of defection to a different provider.

Table 2. Research on the direct effect of group conformity on loyalty in service industries

\begin{tabular}{|c|c|c|c|c|c|}
\hline Study & Aim & Method & Industry & Main conclusion & Coefficient \\
\hline $\begin{array}{l}\text { Toker- } \\
\text { Yildiz et } \\
\text { al. } \\
(2017)\end{array}$ & $\begin{array}{l}\text { Study the impact of online social } \\
\text { interactions and monetary } \\
\text { incentives on consumers' repeat } \\
\text { usage behaviour }\end{array}$ & $\begin{array}{l}\text { Bayesian } \\
\text { inference, } \\
\text { spatial } \\
\text { Tobit model }\end{array}$ & $\begin{array}{l}\text { Online wellness } \\
\text { programme }\end{array}$ & $\begin{array}{l}\text { Social interactions are more } \\
\text { effective than monetary } \\
\text { incentives when both are } \\
\text { present }\end{array}$ & $\begin{array}{l}0.181 * * \\
\text { (network } \\
\text { size) }\end{array}$ \\
\hline $\begin{array}{l}\text { Gu et al. } \\
\text { (2016) }\end{array}$ & $\begin{array}{l}\text { Understand the factors that } \\
\text { influence users' continuance } \\
\text { intention and loyalty }\end{array}$ & PLS-SEM & $\begin{array}{l}\text { Social } \\
\text { networking sites }\end{array}$ & $\begin{array}{l}\text { Relational bonds and social } \\
\text { influence affect the continued } \\
\text { use and loyalty of individuals } \\
\text { to specific services }\end{array}$ & $0.190 * * *$ \\
\hline $\begin{array}{l}\text { Lucia- } \\
\text { Palacios } \\
\text { et al. } \\
(2016)\end{array}$ & $\begin{array}{l}\text { Examine the effect of inertia on } \\
\text { the likelihood of switching to } \\
\text { cloud services }\end{array}$ & PLS-SEM & Cloud services & $\begin{array}{l}\text { The research indicates that } \\
\text { social pressure (subjective } \\
\text { norms) can explain the usage } \\
\text { of cloud services }\end{array}$ & $0.244 * *$ \\
\hline $\begin{array}{l}\text { Ruiz- } \\
\text { Mafe et } \\
\text { al. } \\
(2016)\end{array}$ & $\begin{array}{l}\text { Analyse the role of social } \\
\text { influences on loyalty formation } \\
\text { towards online travel communities }\end{array}$ & CB-SEM & $\begin{array}{l}\text { Online travel } \\
\text { community sites }\end{array}$ & $\begin{array}{l}\text { Subjective norm has a direct } \\
\text { influence on loyalty towards } \\
\text { an online travel community }\end{array}$ & $0.324 * * *$ \\
\hline $\begin{array}{l}\text { Saleem } \\
\text { et al. } \\
(2016)\end{array}$ & $\begin{array}{l}\text { Explore the effects of social } \\
\text { influence and other variables on } \\
\text { customer loyalty }\end{array}$ & CB-SEM & $\begin{array}{l}\text { Banking } \\
\text { industry }\end{array}$ & $\begin{array}{l}\text { Social influence has no direct } \\
\text { effect on customer loyalty }\end{array}$ & n.s. \\
\hline Tsai and & Investigate how online community & CB-SEM & Online retail & Community participation & $0.22 * * *$ \\
\hline Pai 2012 & $\begin{array}{l}\text { building affects development of } \\
\text { relationships with customers }\end{array}$ & & & $\begin{array}{l}\text { elicits community } \\
\text { identification, which in turn } \\
\text { influences loyalty intentions }\end{array}$ & \\
\hline $\begin{array}{l}\text { Nitzan } \\
\text { and Libai } \\
(2011)\end{array}$ & $\begin{array}{l}\text { Explore the role of customers' } \\
\text { social network in their defection } \\
\text { from a service provider }\end{array}$ & $\begin{array}{l}\text { Survival } \\
\text { analysis - } \\
\text { proportional } \\
\text { hazard }\end{array}$ & $\begin{array}{l}\text { Mobile phone } \\
\text { communications }\end{array}$ & $\begin{array}{l}\text { Social variables increase the } \\
\text { explaining power of the } \\
\text { customer defection model }\end{array}$ & $\begin{array}{l}0.586^{* * *} \\
\text { (exposure to } \\
\text { defectors) }\end{array}$ \\
\hline $\begin{array}{l}\text { Lee et al. } \\
(2010)\end{array}$ & $\begin{array}{l}\text { Investigate the social identities and } \\
\text { influences which underpin } \\
\text { consumer preferences for national } \\
\text { brands }\end{array}$ & $\begin{array}{l}\text { Bayesian } \\
\text { structural } \\
\text { equation } \\
\text { modelling }\end{array}$ & $\begin{array}{l}\text { Mobile phone } \\
\text { communications }\end{array}$ & $\begin{array}{l}\text { Identification with ethnicity } \\
\text { (ethnocentrism) is stronger } \\
\text { than identification with social } \\
\text { groups in determining } \\
\text { preference for national } \\
\text { brands }\end{array}$ & $\begin{array}{l}0.359 * * * \\
\text { (ethnoc.) } \\
0.045 \mathrm{n} . \mathrm{s} . \\
\text { (social } \\
\text { groups) }\end{array}$ \\
\hline
\end{tabular}

Note: ${ }^{\text {n.s. }}$ Not significant. ${ }^{* *}$ Significant at the 5 percent level. $* * *$ Significant at the 1 percent level.

In summary, the management literature suggests that when special customers, who are seen by others as 'significant', acquire certain products or services, such acquisitions can be seen as an expression of their behaviours and attitudes. Consumers who identify with those 'significant people' may wish to replicate those attitudes and behaviours through the purchase of the same 
products or services (Hornsey and Jetten, 2005).

Social influence of reference groups can play an even more "vital role in decisions where product choice is complex, specifically, when goods are homogenous and differentiating elements are too vague' (Saleem et al., 2016). The same may occur with services, especially with credence services. Credence services are characterised by a difficulty on the part of the customer to assess the technical quality of the service provided (Kerschbamer et al., 2017), who assess the service based mostly on the quality of the interpersonal relationship (Chandrasekaran et al., 2012; Tinoco et al., 2017). Examples include education, car repair, insurance, and healthcare. In such services, healthcare included, the influence of reference groups on customer loyalty should be high, because customers have difficulty assessing the quality of the services by themselves and may rely more on other opinions when choosing a service provider.

In the healthcare management literature, however, there are no studies addressing the relationship between group conformity and loyalty. Consequently, Maslow's (1970) theory of human motivation is used to hypothesise a relationship between these variables. According to Maslow (1970), health and group belonging are two human needs. Health is part of the safety needs (level 2), and group belonging is part of the love/belonging needs (level 3). When a lower level need (health) is unmet, fulfilling this need (health) takes precedence over other needs (group conformity) (Maslow, 1970; Zalenski and Raspa, 2006; Taormina and Gao, 2013). According to this theory, when health is at stake, individuals should be insensitive to conformity pressures, because group conformity is a need that is on the next level of Maslow's (1970) pyramid. Maslow's (1970) hierarchy of needs, consequently, suggests an insignificant relationship between conformity and loyalty, which is at odds with the previously reviewed management literature.

There are exceptions to Maslow's hierarchy of needs (Maslow, 1970; Compton, 2018). For instance, individuals' creativity or high ideals may override basic needs (Maslow, 1970:51-53; Tsai et al., 2017; Compton, 2018), and extreme poverty may lead belonging needs to override safety needs (Tai and Diener, 2011). It is not clear whether patients in these exceptional circumstances would conform to group influence or not. Tay and Diener (2011), for instance, did not consider health care needs in their study. Thus, these exceptions cannot be considered to support any kind of relationship between group conformity and patient loyalty. Accordingly, it can only be concluded from Maslow's (1970) hierarchy of needs that, exceptions apart, there should be an insignificant relationship between these variables. The inconsistency between this proposition and that from the management literature makes it relevant to assess whether patient loyalty towards healthcare institutions is dependent on pressures exerted by a reference group or not. Thus, the second hypothesis is:

H2: Patient group conformity positively affects patient loyalty.

From the perspective of the patient, quality assessment involves considerations of (1) technical competence, (2) interpersonal relationship, and (3) the amenities of the setting of care (Donabedian, 1980). When an organisation delivers service quality on these three dimensions, it makes the customer adopt a positive view about the service attributes and thereby ensures customer satisfaction (Cândido and Morris, 2000; Cândido, 2005). Satisfaction can be defined as 'pleasurable fulfilment': the 'consumption fulfils some need ... and ... this fulfilment is pleasurable' (Oliver, 1999). A satisfied consumer senses that their expectations have been met, and favourably judges the service (Donabedian, 1980). Consequently, in the management literature, authors seem to agree that perceived quality acts as a trigger to satisfaction (Teas, 1994; Johnson et al., 2001; Juga et al., 2010; Hussain et al., 2019). In the specific case of the healthcare sector, Moliner (2009) and Han and Hyun (2015) also noted the positive impact of service quality on patient satisfaction in public and private hospitals. Finally, Zhou et al. (2017), in their integrative review of the literature on loyalty antecedents in the healthcare sector, report that nine out of the 13 studies reviewed show empirical evidence of the direct impact of service 
quality on patient satisfaction. Thus, the majority of the literature reviewed suggests the following hypothesis:

H3: Perceived service quality positively affects patient satisfaction.

Price is the sum of all values that a customer must give up to use the service (Kotler et al., 2017). It may be paid directly to the service provider, or it may be paid indirectly, partially or in full, through insurance companies or income tax. Price is a key variable to achieving marketing goals (Kotler et al., 2017) because it is the most important factor influencing customer decisions (Kotler and Lee, 2007). Martín-Consuegra et al. (2007) also note that price is one of the most important factors affecting customer satisfaction and suggest that a price increase is perceived as acceptable to customers if the service conveys greater satisfaction. On the company side, price is determined by taking into consideration perceived value, product cost, competition, marketing strategy, and market demand (Kotler et al., 2017). Similarly, on the customer's side, the client makes an assessment (perception) of the price based on several factors. Perceived price can depend on the monetary cost of the service, prices of rival services, perceived value of the service, perceived production costs, and other factors (Jin et al., 2016; Han et al., 2019). The literature has defined price perception simply as a comparison of the price with the prices of rival companies (e.g., Han et al., 2019) and, more comprehensively, to include an assessment of the perceived benefits of the service (e.g., Jin et al., 2016). Price perception is the result of a complex customer assessment, that requires significant effort (Jin et al., 2016), and has a significant impact on customer satisfaction (Martín-Consuegra et al., 2007).

In the healthcare sector, a price strategy must also be carefully assessed, because an appropriate price is one of the features patients value most (Moliner, 2009; Lobo et al., 2014, Han and Hyun, 2015), especially if the price is not to be covered by an insurance company or public budget, but directly, and in full, by the patient. In healthcare, price contributes to customer satisfaction (Lobo et al., 2014) and is often a determining factor that makes customers want to maintain the relationship with the service provider (Moliner, 2009; Han and Hyun, 2015). Price perception is a significant variable in determining patient intentions to revisit medical facilities (Han and Hyun, 2015), although its impact on patient satisfaction remains unclear (Lobo et al., 2014). Thus, the fourth hypothesis is:

H4: Perceived service price positively affects patient satisfaction.

In the management literature, customer satisfaction is a factor to take into account regarding the formation of customer loyalty (Oliver, 1980; Johnson et al., 2001; Juga et al., 2010; Han et al., 2011; Li, 2015; Kim and Kang, 2016; Wang and Zhang, 2018; Mohd-Any et al., 2019). Kotler et al. (2017) note that customer satisfaction is a necessary component to loyalty. And Ofori et al. (2018) conclude that satisfaction is the most important loyalty factor. Concurrently, several empirical studies have shown evidence to support the claim that, over time, with repeated product/service experiences, satisfactory experiences will accumulate and evolve into attitudinal loyalty, intention to repurchase, and actual repurchase (e.g., Oliver, 1980; Han et al., 2011; Liu-Thompkins and Tam, 2013; Kim and Kang, 2016). However, Oliver (1980; 1999) states that customer satisfaction does not always translate into loyalty and Teng (2018) suggests a customer loyalty model, without a satisfaction variable, that explains the majority of the variance in loyalty data. Other factors, such as inertia and group conformity, can contribute to customer loyalty, independently of the customer being satisfied or not (Oliver, 1999; Lin and Sun, 2009; Han et al., 2011).

In the healthcare sector, Martínez-Caro et al. (2013) stresses the importance of developing proper actions to increase patient satisfaction, because of the relationship between satisfaction and loyalty. $\mathrm{Wu}(2011 \mathrm{~b})$ also establishes a positive relationship between satisfaction and loyalty in the healthcare sector. And, in their integrative review, Zhou et al. (2017) propose a conceptual model where satisfaction is a central determinant of patient loyalty. All 13 studies reviewed by 
Zhou et al. (2017) considered satisfaction as an antecedent variable leading directly or indirectly to patient loyalty, and 11 of these studies found a significant relationship. Thus, the last hypothesis is:

H5: Patient satisfaction positively affects patient loyalty.

The literature reviewed and the research hypotheses suggest that inertia, group conformity and satisfaction are loyalty antecedents, and that perceived quality and perceived price are satisfaction antecedents. These relationships between variables, along with the expected signs of the relationships and research hypotheses, are depicted in the research conceptual model, illustrated in Figure 1.

Figure 1. Research model and hypotheses

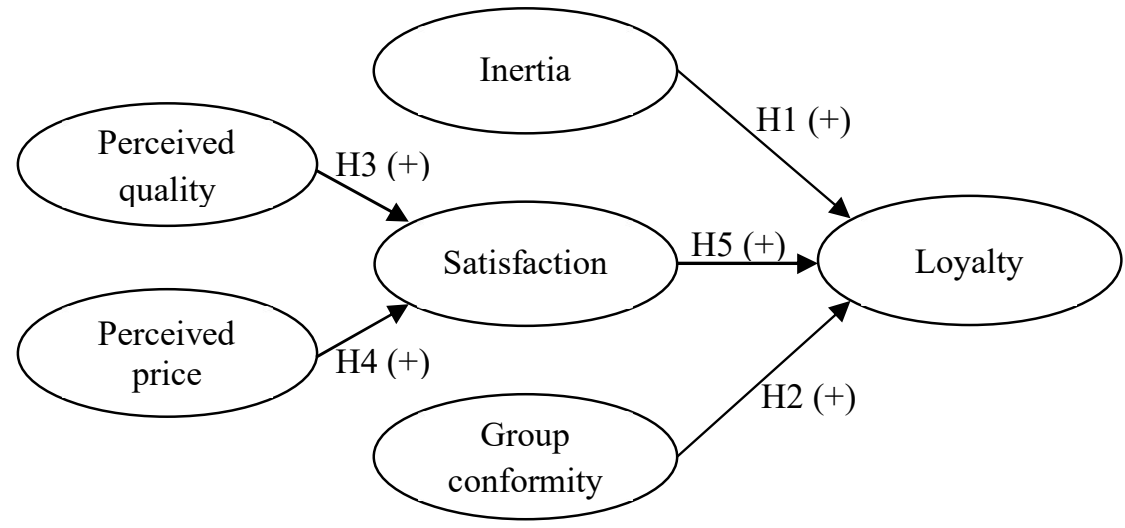

\section{Methodology}

\subsection{Population, sample and statistical power}

The study population was defined as the patients seen or treated in the South Hospitals group. South Hospitals ( $\mathrm{SH}$ ) is a fictitious name adopted to designate a private group of five hospitals and 12 clinics located mainly in the Algarve, Portugal.

The sample size required for partial least squares structural equation modelling (PLS-SEM) is much smaller than for covariance-based structural equation modelling (CB-SEM; Hair et al., 2014). A frequently used rule of thumb to calculate sample sizes recommended 30 respondents for this study (Hair et al., 2014). However, the sample size was determined with a more appropriate method based on the power of the statistical test involved in the assessment of the significance of the model's $\mathrm{R}^{2}$ (Hair et al., 2014). According to this method, with a sample size of 53, this study can detect $\mathrm{R}^{2}$ values of at least $0.50(\geq 0.50)$, with a power of $80 \%$ and a significance level of $1 \%$ (Hair et al., 2014). This sample size (53) is adequate for the study because the $\mathrm{R}^{2}$ obtained in the research is $0.559(>0.50)$. However, considering that the average response rate to email enquiries is low, $10 \%$ to $20 \%$, the researchers conservatively decided to send 700 questionnaires. Thanks to this decision, the total number of valid responses received was 94, almost double of the minimum sample size required (53). This larger sample size is preferable, because it allows the detection of smaller $\mathrm{R}^{2}$ values. In fact, this sample size allows the detection of $\mathrm{R}^{2}$ values of at least $0.25(\geq 0.25)$, with a power of $80 \%$ and a significance level of $1 \%$ (Hair et al., 2014), which is adequate, given the $\mathrm{R}^{2}$ obtained in this research $(0.559)$.

\subsection{Questionnaire and variables measurement}

The questionnaire comprised seven groups of questions. The first six groups collected data for the latent variables in the research. Respondents had to provide answers to several measurement items in terms of their degree of agreement or disagreement, using seven-point rating scales. All scales, measurement items and latent variables' definitions are shown in Table 3. The scales adopted in the research have been developed and tested before in previous studies. 
The first two scales were developed specifically for the healthcare sector, and the four remaining scales were adapted by the researchers to the healthcare sector through careful rewording. The remainder group of queries in the questionnaire aimed at a description of the respondents in terms of age, education, income, and other relevant aspects.

Table 3. Measurement instrument

\begin{tabular}{|c|c|c|}
\hline Construct & Items & $\begin{array}{l}\text { Type / } \\
\text { Study }\end{array}$ \\
\hline $\begin{array}{l}\text { Perceived quality } \\
\text { (Perceived quality of the } \\
\text { service received, from the } \\
\text { patient's perspective) }\end{array}$ & $\begin{array}{l}\text { 1.1. The hospital was well organized } \\
\text { 1.2. Service quality was maintained throughout the contact with the hospital } \\
\text { 1.3. It has an acceptable level of quality, if we compare it to other hospitals } \\
\text { 1.4. The staff were always kind and friendly } \\
\text { 1.5. The medical team got the diagnosis and the treatment right }\end{array}$ & $\begin{array}{l}\text { Reflective. } \\
\text { Moliner } \\
(2009) \text {. }\end{array}$ \\
\hline $\begin{array}{l}\text { Perceived price } \\
\text { (Monetary cost of service } \\
\text { relative to perceived value and } \\
\text { reference price) }\end{array}$ & $\begin{array}{l}\text { 2.1. The money spent was well worth it } \\
\text { 2.2. Service cost was not high } \\
\text { 2.3. The service was good for what I have paid }\end{array}$ & $\begin{array}{l}\text { Reflective. } \\
\text { Moliner } \\
\text { (2009). }\end{array}$ \\
\hline $\begin{array}{l}\text { Satisfaction } \\
\text { (Evaluation of the purchase } \\
\text { experience, a function of } \\
\text { expectation and expectancy } \\
\text { disconfirmation) }\end{array}$ & $\begin{array}{l}\text { 3.1. I was satisfied with my decision to go to the private hospital } \\
\text { 3.2. My visit to the private hospital changed for the better my perspective } \\
\text { on private hospitals } \\
\text { 3.3. My choice to go to the private hospital was a wise one } \\
\text { 3.4. I feel bad about my decision to go to the private hospital [reversed } \\
\text { scaling, scores were reversed previous to computations] } \\
\text { 3.5. I think that I did the right thing when I decided to go to the private } \\
\text { hospital } \\
\text { 3.6. I am not happy that I went to the private hospital [reversed scaling, } \\
\text { scores were reversed previous to computations] }\end{array}$ & $\begin{array}{l}\text { Reflective. } \\
\text { Oliver } \\
\text { (1980), } \\
\text { Chuah et } \\
\text { al. (2017). }\end{array}$ \\
\hline $\begin{array}{l}\text { Inertia } \\
\text { (Individual's apathetic state that } \\
\text { contributes to maintain his/her } \\
\text { habits/routines and to prevent } \\
\text { behavioural change) }\end{array}$ & $\begin{array}{l}\text { 4.1. Unless other hospitals provide very advantageous conditions, I intend } \\
\text { to keep the services of the private hospital } \\
\text { 4.2. Unless I became very dissatisfied with the private hospital, changing to } \\
\text { a new one would be a bother } \\
\text { 4.3. Unless I became very dissatisfied with the private hospital, switching to } \\
\text { a new one would be very inconvenient for me } \\
\text { 4.4. For me, the costs in time, money and effort to switch hospitals are high } \\
\text { 4.5. In general, it would be a hassle changing hospitals } \\
\text { 4.6. It would take a lot of time and effort changing hospitals }\end{array}$ & $\begin{array}{l}\text { Reflective. } \\
\text { Han et al., } \\
(2011) \text {, } \\
\text { Chuah et } \\
\text { al. }(2017) \text {. }\end{array}$ \\
\hline $\begin{array}{l}\text { Group conformity } \\
\text { (Normative conformity, } \\
\text { normative dimension of the social } \\
\text { influence trough which } \\
\text { individuals replicate the } \\
\text { behaviours of a reference group) }\end{array}$ & $\begin{array}{l}\text { 5.1. If I want to be like someone, I often try to choose the same hospital } \\
\text { 5.2. It is important to me that others like the hospital I choose } \\
5.3 \text {. I rarely choose a new hospital until I am sure my friends approve it } \\
\text { 5.4. I often identify with other people by choosing the same hospital they } \\
\text { attend } \\
5.5 \text {. When choosing an hospital, I choose the one I think others will approve } \\
\text { of } \\
5.6 \text { I I like to know what hospitals make good impressions on others } \\
\text { 5.7. If others can see I choose an hospital, I often go with the one they } \\
\text { expect me to choose } \\
\text { 5.8. I achieve a sense of belonging by choosing an hospital that others } \\
\text { choose }\end{array}$ & $\begin{array}{l}\text { Reflective. } \\
\text { Bearden et } \\
\text { al. (1989), } \\
\text { Ruiz-Mafe } \\
\text { et al. } \\
\text { (2016). }\end{array}$ \\
\hline $\begin{array}{l}\text { Loyalty } \\
\text { (Loyalty operationalized as } \\
\text { repurchase intentions and word- } \\
\text { of-mouth) }\end{array}$ & $\begin{array}{l}\text { 6.1. I say positive things about the private hospital to other people } \\
\text { 6.2. I recommend the private hospital to someone who seeks my advice } \\
\text { 6.3. I encourage friends and relatives to go to the private hospital } \\
\text { 6.4. I consider the private hospital my first choice when I need medical care } \\
\text { 6.5. I intend to attend the private hospital in the future }\end{array}$ & $\begin{array}{l}\text { Reflective. } \\
\text { Zeithaml } \\
\text { et al. } \\
\text { (1996), } \\
\text { Ruiz-Mafe } \\
\text { et al. } \\
(2016) \text {. }\end{array}$ \\
\hline
\end{tabular}

A pre-test with six patients permitted some minor improvements in the wording of the items. The survey was approved by management of the SH and informed consent was obtained from all questionnaire respondents. Ex ante precautions to avoid common-method bias (Podsakoff et al., 2003) included informing respondents that their responses would be kept anonymous, that there were no right or wrong answers to the questions, and that respondents should answer as honestly as possible. 


\subsection{Data analysis}

Data analysis included descriptive statistics to characterise the questionnaire respondents and to portray the types of data distributions obtained; non-randomness, non-response bias and common-method bias tests to assess the sample data, and PLS-SEM conducted with SmartPLS (Ringle et al., 2005) to determine the coefficients of the relationships between research variables.

\section{Results}

\subsection{Sample data}

The respondents are mainly Portuguese (81.9\%; Table 4), who live in the Algarve $(72.3 \%)$, aged between 31 and 45 years (41.5\%), with higher education $(78.7 \%)$, and a monthly income between 600 and 1,500 euros (59.6\%). They have health insurance $(57.4 \%)$, are a beneficiary of a Portuguese healthcare subsystem (75.5\%), and have visited an SH hospital two to five times during 2012 (57.4\%; Table 4).

Table 4. Sample demographics

\begin{tabular}{|c|c|c|}
\hline Demographics & Frequency & Percentage \\
\hline \multicolumn{3}{|l|}{ Nationality } \\
\hline Portuguese & 77 & 81.9 \\
\hline British & 13 & 13.8 \\
\hline Other & 4 & 4.3 \\
\hline \multicolumn{3}{|l|}{ Residence } \\
\hline Algarve & 68 & 72.3 \\
\hline Portugal (remainder of) & 23 & 24.5 \\
\hline Abroad & 3 & 3.2 \\
\hline \multicolumn{3}{|l|}{ Age } \\
\hline $19-30$ & 23 & 24.5 \\
\hline $31-45$ & 39 & 41.5 \\
\hline $46-65$ & 24 & 25.5 \\
\hline$>65$ & 8 & 8.5 \\
\hline \multicolumn{3}{|l|}{ Education } \\
\hline Secondary or less & 20 & 21.3 \\
\hline Higher & 74 & 78.7 \\
\hline \multicolumn{3}{|l|}{ Income } \\
\hline$<600 €$ & 6 & 6.4 \\
\hline $600 €-1500 €$ & 56 & 59.6 \\
\hline $1500 €-3000 €$ & 26 & 27.7 \\
\hline$>3000 €$ & 6 & 6.4 \\
\hline \multicolumn{3}{|l|}{ Health insurance } \\
\hline Yes & 54 & 57.4 \\
\hline No & 40 & 42.6 \\
\hline \multicolumn{3}{|c|}{$\begin{array}{l}\text { Beneficiary of a Portuguese health } \\
\text { care subsystem }\end{array}$} \\
\hline Yes & 71 & 75.5 \\
\hline No & 23 & 24.5 \\
\hline \multicolumn{3}{|l|}{ Visited an HA hospital } \\
\hline 2 times & 27 & 28.7 \\
\hline 3-5 times & 27 & 28.7 \\
\hline$>5$ times & 16 & 17.0 \\
\hline No answer & 24 & 25.5 \\
\hline
\end{tabular}

Note: Sample size $n=94$.

Symmetry and flatness values are significantly different from normal; however, nonnormal data distribution is common in management research and constitutes no problem, because PLS-SEM does not require normally distributed data (Hair et al., 2014). 
Randomness, however, is a basic condition for PLS-SEM. All p-values of the Runs tests conducted are higher than 0.05, suggesting that the null hypotheses of sample randomness should not be rejected. Evidence suggests that the research sample is random.

Non-response bias was examined with the Kruskal-Wallis test. The sample was divided into two halves. One half composed of the early respondents to the questionnaire and the other half composed of later respondents. For the large majority of the research items (91\%), there are no significant differences between the two halves (Kruskal-Wallis $\mathrm{p}>0.05$ ), which suggests that there is no evidence of non-response bias.

Finally, to assess common-method variance, the authors performed Harman's single-factor test. The single factor extracted explained $27 \%$ of the total variance, which is lower than the $50 \%$ threshold (Podsakoff et al., 2003) and, together with the precautions mentioned in Section 3.2 , suggests that there is no common-method bias.

\subsection{Analysis of the measurement model}

Analysis of the measurement model included the assessment of internal consistency reliability, convergent validity, and discriminant validity. Regarding the internal consistency reliability of the measurement model, all latent variables have composite reliability and Cronbach alpha values higher than 0.7 (Table 5), which are considered appropriate (Hair et al., 2014) and indicative of good internal consistency.

Regarding the convergent validity of the measurement model, all latent variables show average variance extracted (AVE) values above 0.5 (Table 5), which is considered appropriate (Hair et al., 2014), and most indicators have loadings above 0.7 (Table 5), which is also considered appropriate (Hair et al., 2014). However, some indicators (of perceived quality, satisfaction, inertia, and group conformity) have loadings between 0.4 and 0.7 . Indicators 5.4, 5.5 and 5.6 were removed, leading to an increase in composite reliability and AVE (Table 5). Content validity was not affected, because all items in the group conformity scale measure the same dimension (normative dimension, cf. Table 3). The other latent variables' indicators with loadings between 0.4 and 0.7 were not removed, because their removal would not improve the corresponding variable's composite reliability, nor AVE (Hair et al., 2014).

Finally, the discriminant validity of the measurement model was examined. All indicator's loadings are higher than all of its cross-loadings (Hair et al., 2014) and the Fornell-Larcker criterion analysis revealed that the square root of each latent variable's AVE is higher than its correlations with all other constructs (Table 6; Hair et al., 2014). This is indicative of adequate discriminant validity. In summary, the analysis of the measurement model suggests that all relevant criteria are met and, consequently, the indicators are valid and reliable to measure the corresponding latent variables.

\subsection{Analysis of the structural model}

First, the structural model was inspected for collinearity. This examination involves a comparison of all variance inflator factors (VIF) with the recommended threshold of five (Hair et al., 2014). All VIF values are very close to one (Table 6), and smaller than the recommended threshold, which suggests that the structural model's latent variables are free of any collinearity issues.

Next, the coefficient of determination $\mathrm{R}^{2}$ was assessed. The endogenous variable customer satisfaction's $\mathrm{R}^{2}$ value is 0.455 , while the endogenous variable customer loyalty's $\mathrm{R}^{2}$ value is 0.559 (Table 5). These are satisfactory and appropriate values, according to Hair et al. (2014), and suggest that the model explains the endogenous variables' behaviour. They are also very similar to those of Johnson et al.'s (2001) seminal work, but with less latent variables and path coefficients than those in Johnson's models. This suggests that the research model in Figure 1 is parsimonious.

The predictive relevance of the model was next assessed with $\mathrm{Q}^{2}$ and a blindfolding technique. Following Hair et al.'s (2014) recommendations, the computation method adopted 
an omission distance of seven, resulting in $\mathrm{Q}^{2}$ values larger than zero (Table 5), which is indicative of the predictive relevance of the exogenous variables.

Table 5. Measurement model statistics, $\mathrm{R}^{2}$ and $\mathrm{Q}^{2}$

\begin{tabular}{|c|c|c|c|c|c|c|c|c|c|c|}
\hline $\begin{array}{c}\text { Latent } \\
\text { variable }\end{array}$ & Item & Mean & SD & Loading & p-value & AVE & $\begin{array}{c}\text { Cronbach } \\
\text { alpha }\end{array}$ & $\begin{array}{l}\text { Composite } \\
\text { reliability }\end{array}$ & $\mathrm{R}^{2}$ & $\mathrm{Q}^{2}$ \\
\hline \multirow{5}{*}{$\begin{array}{l}\text { Perceived } \\
\text { quality }\end{array}$} & 1.1 & 5.894 & 0.916 & 0.612 & $0.000 * * *$ & 0.548 & 0.791 & 0.857 & - & - \\
\hline & 1.2 & 5.840 & 0.971 & 0.823 & $0.000^{* * *}$ & & & & & \\
\hline & 1.3 & 6.053 & 0.720 & 0.785 & $0.000^{* * *}$ & & & & & \\
\hline & 1.4 & 6.074 & 0.992 & 0.760 & $0.000^{* * *}$ & & & & & \\
\hline & 1.5 & 5.734 & 1.150 & 0.702 & $0.000^{* * *}$ & & & & & \\
\hline \multirow{3}{*}{$\begin{array}{l}\text { Perceived } \\
\text { price }\end{array}$} & 2.1 & 5.330 & 1.447 & 0.953 & $0.000^{* * *}$ & 0.912 & 0.952 & 0.969 & - & - \\
\hline & 2.2 & 5.117 & 1.563 & 0.934 & $0.000^{* * * *}$ & & & & & \\
\hline & 2.3 & 5.128 & 1.496 & 0.977 & $0.000^{* * *}$ & & & & & \\
\hline \multirow[t]{6}{*}{ Satisfaction } & 3.1 & 6.021 & 0.934 & 0.891 & $0.000^{* * *}$ & 0.567 & 0.842 & 0.883 & 0.455 & 0.224 \\
\hline & 3.2 & 5.117 & 1.236 & 0.538 & $0.000^{* * *}$ & & & & & \\
\hline & 3.3 & 5.915 & 1.069 & 0.910 & $0.000^{* * *}$ & & & & & \\
\hline & 3.4 & 6.245 & 1.098 & 0.564 & $0.000^{* * *}$ & & & & & \\
\hline & 3.5 & 5.957 & 0.988 & 0.854 & $0.000 * * *$ & & & & & \\
\hline & 3.6 & 6.255 & 1.091 & 0.666 & $0.000^{* * *}$ & & & & & \\
\hline \multirow[t]{6}{*}{ Inertia } & 4.1 & 5.521 & 1.335 & 0.711 & $0.000^{* * *}$ & 0.565 & 0.859 & 0.886 & - & - \\
\hline & 4.2 & 4.255 & 1.935 & 0.632 & $0.000^{* * *}$ & & & & & \\
\hline & 4.3 & 4.287 & 1.730 & 0.760 & $0.000^{* * *}$ & & & & & \\
\hline & 4.4 & 3.915 & 1.790 & 0.762 & $0.000^{* * *}$ & & & & & \\
\hline & 4.5 & 4.170 & 1.766 & 0.834 & $0.000^{* * *}$ & & & & & \\
\hline & 4.6 & 3.564 & 1.754 & 0.796 & $0.000^{* * *}$ & & & & & \\
\hline \multirow{5}{*}{$\begin{array}{l}\text { Group } \\
\text { conformity }\end{array}$} & 5.1 & 2.585 & 1.789 & 0.832 & $0.000 * * *$ & 0.528 & 0.818 & 0.846 & - & - \\
\hline & 5.2 & 2.298 & 1.556 & 0.807 & $0.001 * * *$ & & & & & \\
\hline & 5.3 & 1.979 & 1.321 & 0.578 & $0.061^{*}$ & & & & & \\
\hline & 5.7 & 1.362 & 0.697 & 0.731 & $0.012 * *$ & & & & & \\
\hline & 5.8 & 1.745 & 1.139 & 0.655 & $0.031 * *$ & & & & & \\
\hline \multirow[t]{5}{*}{ Loyalty } & 6.1 & 5.521 & 1.049 & 0.817 & $0.000 * * *$ & 0.685 & 0.885 & 0.916 & 0.559 & 0.347 \\
\hline & 6.2 & 5.362 & 1.228 & 0.885 & $0.000 * * *$ & & & & & \\
\hline & 6.3 & 4.979 & 1.368 & 0.837 & $0.000^{* * *}$ & & & & & \\
\hline & 6.4 & 4.745 & 1.688 & 0.794 & $0.000^{* * *}$ & & & & & \\
\hline & 6.5 & 5.606 & 1.214 & 0.803 & $0.000^{* * *}$ & & & & & \\
\hline
\end{tabular}

Notes: * Significant at the 10 percent level. ** Significant at the 5 percent level. ${ }^{* * *}$ Significant at the 1 percent level. Bilateral p-values. Sample size $n=94$.

Then, the total effects were examined. The procedure evaluates the importance of the exogenous variables in explaining the endogenous variables to which they are linked (Hair et al., 2014). The variable with the highest total effect in customer loyalty's explanation is customer satisfaction (0.504), followed by inertia (0.395), and perceived price (0.234). Group conformity has little effect (0.045). As for the explanation of customer satisfaction, the variable that presents a higher total effect is perceived price $(0.464)$, followed by perceived quality (0.349).

So far, group conformity has been the variable that presents less consistent results in the SEM analysis, and its removal from the model was considered. However, the removal of this latent variable did not improve the results, neither in the measurement model, nor in the structural model.

Lastly, a bootstrap analysis was conducted to evaluate the path coefficients' significance. The analysis shows that all path coefficients exhibit a positive sign (Table 7), which is in accordance with the research hypotheses. In addition, the path coefficients of all latent variables 
are statistically significant at the $1 \%$ level ( $\mathrm{p}$-value $=0.000$ ), with the exception of group conformity ( $p$-value $=0.370$ ). Consequently, the analysis in this study empirically supports all research hypotheses, with the exception of hypothesis 2 (Table 7).

Table 6. Correlation matrix, square root of AVE and inner model VIF values

\begin{tabular}{lcccccc}
\hline \multicolumn{1}{c}{ Latent variable } & PQ & PP & S & I & GC & L \\
\hline Perceived quality (PQ) & $\mathbf{0 . 7 4 0}$ & & 1.152 & & & \\
Perceived price (PP) & 0.363 & $\mathbf{0 . 9 5 5}$ & 1.152 & & & \\
Satisfaction (S) & 0.518 & 0.591 & $\mathbf{0 . 7 5 3}$ & & & 1.133 \\
Inertia (I) & 0.272 & 0.247 & 0.322 & $\mathbf{0 . 7 5 2}$ & & 1.171 \\
Group conformity (GC) & 0.172 & 0.084 & 0.199 & 0.265 & $\mathbf{0 . 7 2 7}$ & 1.092 \\
Loyalty (L) & 0.535 & 0.549 & 0.640 & 0.570 & 0.250 & $\mathbf{0 . 8 2 8}$ \\
\hline
\end{tabular}

Notes: Italicized values above the diagonal are inner model VIF values, bold values in the diagonal are square root of AVE values, and values below the diagonal are correlations.

\section{Discussion and research contributions}

\subsection{How inertia influences loyalty}

The first contribution of this study reveals inertia as an important explanatory variable of customer loyalty. Firstly, inertia exhibits a much stronger effect on loyalty (0.395) in this study than other types of variables have been shown to exert in previous research, e.g., corporate image, affective commitment, calculative commitment (Johnson et al., 2001), customer value (Lam et al., 2004), technology acceptance, website quality (Lin and Sun, 2009), corporate image, and trust (Ofori et al., 2018). This comparison suggests that inertia may be more important than other loyalty antecedents, which, in turn, suggests that inertia should be included more frequently in loyalty research models. Its frequent omission from loyalty models, may lead to model misspecification and biased results, which can only be avoided with the inclusion of this variable. Secondly, the hypotheses development section in this study (Section 2) suggested that inertia's impact on loyalty should be higher in healthcare than in other sectors. A comparison of the inertia structural coefficient (0.395) with those of previous research (Table 1) supports the idea that the inertia-loyalty relationship is, in fact, much stronger in healthcare. One reason why inertia is stronger in healthcare is that both inertia (stability) and freedom from illness (health) are needs at the same low level of Maslow's (1970) pyramid (safety needs), and patients taken ill do not want to lose the reassurance (stability/safety) that results from being cared for by the same service provider with which they are familiar and feel safe. The stronger influence of inertia on loyalty may be specific to the (private) healthcare sector, or it may be a more general characteristic of services that deal with needs at the same level of Maslow's (1970) pyramid (safety level). In particular, it may be a general feature of services that deal with customer safety, such as protection, security, and insurance. Table 8 is an attempt at a generalisation to other services. The results of previous research (see Table 1) can be used to support this generalisation. Lai et al.'s (2011) study, for instance, provides strong evidence in favour of this research implication, because the need satisfied by the service sector considered in this study (compulsory insurance) is at the same level of inertia (safety) and, as such, the high and statistically significant impact of inertia on estimated loyalty $(0.335)$ is as expected. Furthermore, almost all other previous studies, in Table 1 (Lin and Sun, 2009; Wu, 2011a; LiuThompkins and Tam 2013; Kim and Kang, 2016; Lucia-Palacios et al., 2016; Gray et al., 2017), were conducted in services that satisfy needs less important than inertia, in Maslow's hierarchy (phone communications, cloud services, retail), and exhibit positive, significant impacts of inertia on loyalty, which is also consistent with these research implications (Table 8). However, there is also some contrasting evidence. In two of the studies (Liu-Thompkins and Tam, 2013; Gray et al., 2017), the coefficients, although statistically significant, are very small, and in Ranaweera and Neely's (2003) study, the inertia coefficient is small and insignificant. In 
summary, there are a majority of previous studies supporting the prediction made in this study, but more research is needed on this topic.

Table 7. Structural model statistics and hypotheses

\begin{tabular}{lccccccc}
\hline \multicolumn{1}{c}{ Hypotheses } & $\begin{array}{c}\text { Expected } \\
\text { effect }\end{array}$ & $\begin{array}{c}\text { Original } \\
\text { sample }(\mathrm{O})\end{array}$ & $\begin{array}{c}\text { Sample } \\
\text { mean }(\mathrm{M})\end{array}$ & $\begin{array}{c}\text { Standard } \\
\text { deviation }(\mathrm{SD})\end{array}$ & $\begin{array}{c}\mathrm{t} \text { statistic } \\
(|\mathrm{O} / \mathrm{SD}|)\end{array}$ & p-values & Hypothesis \\
\hline H1 Inertia $\rightarrow$ Loyalty & + & 0.395 & 0.393 & 0.074 & 5.361 & $0.000^{* * * *}$ & Supported \\
$\mathrm{H}$ H Group conformity $\rightarrow$ & + & 0.045 & 0.061 & 0.135 & 0.334 & 0.370 & Not Supp. \\
$\quad \begin{array}{l}\text { Loyalty } \\
\text { H3 Perceived Quality } \rightarrow\end{array}$ & + & 0.349 & 0.369 & 0.069 & 5.095 & $0.000^{* * *}$ & Supported \\
$\quad \begin{array}{l}\text { Satisfaction } \\
\text { H4 Perceived price } \rightarrow\end{array}$ & + & 0.464 & 0.452 & 0.078 & 5.985 & $0.000^{* * *}$ & Supported \\
$\quad \begin{array}{l}\text { Satisfaction } \\
\text { H5 Satisfaction } \rightarrow \text { Loyalty }\end{array}$ & + & 0.504 & 0.496 & 0.069 & 7.330 & $0.000^{* * *}$ & Supported \\
\hline
\end{tabular}

Note: *** Significant at the 1 percent level. Unilateral p-values.

\subsection{How group conformity influences loyalty}

The second contribution of this research is the analysis of the relationship between group conformity and customer loyalty in healthcare, which is a type of credence service. Credence services, such as healthcare, are characterised by a difficulty on the part of the customer to assess the technical quality of the service (Kerschbamer et al., 2017). The customer assesses quality mostly based on the quality of the interpersonal relationship (Chandrasekaran et al., 2012; Tinoco et al., 2017). In these services, healthcare included, the influence of reference groups on customer loyalty can be high, because customers have difficulty assessing the quality of the services by themselves and may rely on others' opinions to choose a service provider. This study, however, suggests that group conformity is an insignificant loyalty antecedent in healthcare. One explanation for the small and insignificant path coefficient found (0.045) is that health (safety) and group conformity (belonging) are human needs at different levels of the Maslow (1970) pyramid. The precedence of health over belonging inhibits the drive to satisfy the group conformity need, which leads to a weaker and insignificant relationship with loyalty.

Table 8 . Service needs and the impact of inertia and group conformity on loyalty

\begin{tabular}{|c|c|c|c|}
\hline & $\begin{array}{l}\text { Importance of the customer need that the } \\
\text { industry satisfies is... }\end{array}$ & Impact on loyalty & Example of customer need \\
\hline \multirow[t]{2}{*}{$\begin{array}{l}\text { Current study } \\
\text { results and } \\
\text { implications }\end{array}$} & $\begin{array}{l}\text {..higher than that of group conformity } \\
\text { (belonging need) in Maslow's hierarchy }\end{array}$ & $\begin{array}{l}\text { Impact of group } \\
\text { conformity is positive } \\
\text { but small and } \\
\text { insignificant }\end{array}$ & Health \\
\hline & $\begin{array}{l}\text {...equal to that of inertia (stability need) } \\
\text { in Maslow's hierarchy }\end{array}$ & $\begin{array}{l}\text { Impact of inertia is } \\
\text { positive, high and } \\
\text { significant }\end{array}$ & Health \\
\hline $\begin{array}{l}\text { Generalization } \\
\text { attempt }\end{array}$ & $\begin{array}{l}\text {...higher than that of inertia [group } \\
\text { conformity] need in Maslow's hierarchy } \\
\text {...equal to or lower than that of inertia } \\
\text { [group conformity] in Maslow's } \\
\text { hierarchy }\end{array}$ & $\begin{array}{l}\text { Positive but small and / } \\
\text { or insignificant impact } \\
\text { Positive and significant } \\
\text { impact }\end{array}$ & $\begin{array}{l}\text { Biological and physiological } \\
\text { needs (food, drink, warmth) } \\
\text { Esteem needs (status, } \\
\text { independence, achievement) }\end{array}$ \\
\hline
\end{tabular}

Although group conformity has been found to significantly influence loyalty in other sectors (cf. Table 2), in this study, group conformity does not affect loyalty because of the relationship between the types of needs involved. The more important need (safety/health) takes precedence over the less important need (belonging/group conformity), even in a service where the customer is unable to fully assess the quality being provided and must rely on other opinions to fully assess the quality of the service (credence services).

If, as suggested, the (in)significance of group conformity is a result of the relationship 
between the types of needs involved, then the strength of the group conformity influence over loyalty may vary according to types of services (health, retail, education...). In this sense, this analysis suggests that a weak or insignificant group conformity path coefficient is a distinctive characteristic of the healthcare sector and may also be a more general characteristic of sectors providing services related to safety needs (e.g., protection, security, insurance). In general, this study suggests that, in sectors where the type of customer need that is satisfied is more important than the belonging need (group conformity), there may be an insignificant impact of normative influences on customer loyalty, even in credence service sectors. Conversely, in sectors where the type of customer need that is satisfied is less important than the belonging need (group conformity), there may be a significant impact of normative influences on customer loyalty, especially in the case of credence service sectors. Table 8 is an attempt at a generalisation. The results of previous studies (see Table 2) can be used to support this generalisation. Saleem et al.'s (2016) study, for instance, provides strong evidence in favour of the research implications, because the need satisfied by the service sector considered in their study (banking) is at a higher level than conformity (safety, security) and, as such, the insignificant impact of conformity on loyalty found in that study is as expected. Furthermore, all other previous studies in Table 2 were conducted in services that satisfy needs equally or less important than conformity (phone communications, cloud services, online services, retail) and exhibit positive, significant impacts of group conformity on loyalty, which is also consistent with this research's implications.

The implications suggested here, and the growing relevance of social media in the information age, turns group conformity into a variable that should be considered in more loyalty research, particularly in credence services.

\subsection{Parsimony and bias avoidance}

The third and last contribution of this study is the suggestion of a model that is a parsimonious alternative to other more complex models. Judging by the loyalty $\mathrm{R}^{2}$ value (0.559), which is similar to those in the seminal work of Johnson et al. (2001), the model has the advantage of having much lesser variables and path coefficients (parsimony). The model may retain its parsimony when applied to service industries that satisfy needs which are equally or less important than inertia, in Maslow's (1970) hierarchy of needs. Furthermore, the model may reduce the probability of misspecification errors and biases that can result from the omission of inertia in loyalty models. This research adds evidence to Lucia-Palacios et al.'s (2016) suggestion of bias by omission of inertia and suggests the type of service industries in which that bias may or may not occur.

\section{Practical implications}

This study has implications for healthcare management, regulatory institutions, patients and reference groups. First, there are implications for management. This research shows that inertia and customer loyalty are significantly interrelated. Managers should take this significant relationship into consideration and adjust their company's customer survey on quality and satisfaction by including some inertia and conformity questions in it. In doing so, managers may consider the inertia items that were adapted to the healthcare sector in this study (Table 3 ). Monitoring the level of customer inertia, and the sizes of the least and most 'inert' customer segments, provides a health organisation with a more rigorous assessment of customer loyalty, and can help to anticipate changes in loyalty that may require an adaptation of the organisational strategy.

Managers can further consider inertia's impact on loyalty when developing specific quality and marketing strategies that can help to build mutually beneficial loyalty relationships with patients. These strategies may involve several different aspects, including information management, communication, packages of services, payment methods, price strategies, and other innovative quality and marketing policies. Information technology, for instance, has been 
extensively used by the SH to create online access to all clinical information available on the patient, which is accessible by all clinical staff in contact with the patient in any of the SH hospitals and clinics. This database access creates value to the customer through enhanced customisation (better diagnostics, fewer repeat tests, lower cost) and is something they consider when deciding whether to change service provider, thus creating loyalty through quality and inertia.

Social group membership, however, does not seem to be a significant antecedent to loyalty to private hospitals. Until more research can confirm this result, social media may continue to be used for building loyalty (and for other marketing purposes), because a considerable percentage of respondents $(28 \%)$ replied that their choice of a hospital was in part due to the opinion of others. Actively seeking (or creating) groups in social media and using them to feed information and collect feedback - while at the same time emphasising that active participation from customers can be an effective way to improve services and to protect customer interests may also contribute to customer loyalty.

There are also implications for patients and reference groups. First, 'inert' patients should reconsider the reasons for their loyalty. Loyalty based on inertia may be a wise (or unwise) choice, depending on the price and quality of the current healthcare provider, and on the alternative providers available. Inertia can contribute to a feeling of safety and reassurance, because the patients are being cared for by someone they already know, but inertia can also have considerable costs for the patients (and insurers and the state), if there are less expensive quality alternatives. Consequently, 'inert' patients should carefully reconsider the reasons for their inertia and loyalty. They should seek information and advice on alternative healthcare providers. This is particularly important in the healthcare sector because the influence of inertia on loyalty is higher in this sector. The second implication is that, although this study suggests that group conformity has no significant influence on patient loyalty, more patients should seek impartial reference groups for information and advice. 'Inert' patients should consider alternatives suggested in official communications, and in social and other media. Group conformity may be good (or bad) depending on the type of reference group chosen. It is a responsibility of the patient to carefully assess their reasons for being loyal and finding reference groups that may help him/her in this assessment. 'Inert' patients, however, need regulatory authorities and reference groups to play an important part by carefully preparing and divulging impartial assessments of healthcare service providers though social and other media.

Finally, there are other implications for governments and regulatory authorities. First, they should be vigilant of how and what new forms of inertia exploitation are used by private healthcare providers, particularly those through group membership, social media and other electronic means. Pricing, switching costs, quality of service, loyalty schemes, privacy, and patients' personal information are particular aspects which merit government attention. Hospitals, however, should not neglect their ethical and legal responsibilities. Second, regulatory institutions should be responsible for helping patients assess their current healthcare providers and alternative providers. This involves disclosing data on quality assessments of healthcare institutions, costs, rankings and other information. Regulatory institutions should then stimulate patients to use this information as a means to assess alternative providers and overcome loyalties based on habit or inertia, because these can have considerable costs for the state and for the patient, specifically in those cases where switching service provider would result in savings.

\section{Conclusion}

This research is the first to study the influence of inertia and group conformity on loyalty in the healthcare sector and, from the perspective of Maslow's (1970) hierarchy of needs, it is the first to do so in any service sector. The study reveals that customer inertia and satisfaction 
are statistically significant antecedents of customer loyalty, as hypothesised, but group conformity is not a significant antecedent. The results obtained for inertia are supportive of the conclusions of previous research, in the management literature, but novel in the healthcare sector management field. These novel results have implications for theory and practice, both for healthcare and for other service sectors. The results obtained for group conformity are surprising, because this variable has been considered a significant loyalty antecedent in the management literature, but it is not in the healthcare sector. Nevertheless, this study suggests implications for group conformity theory and practice, both for healthcare and for other service sectors. In particular, this study finds that the strength of the impact of inertia and group conformity on loyalty depends on the customers' need that is satisfied by the service industry. The impact of inertia [group conformity] on loyalty should be small and/or insignificant only in industries where the service need satisfied is, in Maslow's (1970) hierarchy, more important than inertia [group conformity].

\subsection{Limitations}

This study has limitations. Firstly, the electronic enquiry method used might have limited the participation of patients with less computer knowledge. Although a comparison with the samples of similar studies (e.g., Moliner, 2009) did not reveal significant differences in terms of respondents' biographic data, future research might consider alternative data collection methods. Secondly, this study makes a cross-sectional analysis and, as such, assess only two of three necessary conditions for establishing causality relationships, i.e., (1) existence of significant correlation between variables, and (2) ruling out of extraneous variables. The third condition, temporal precedence of the cause (e.g., Cândido and Santos, 2019), cannot be assessed in cross-sectional research. Future research might consider longitudinal methodologies to address this limitation. Thirdly, the scale used in this study for measuring group conformity included normative items only. Future research might consider alternative indicators of group conformity. Lastly, the study took place in private hospitals of the Algarve, Portugal. The specific setting might affect generalisability; although the Portuguese is a European open economy, whose companies face strong international competition, particularly the Algarve's tourism and health organisations (Cândido et al., 2016; Esgarrancho and Cândido, 2020). Nevertheless, future research might consider alternative settings.

\section{Acknowledgment}

The authors are pleased to acknowledge the participation of all survey respondents. The authors would also like to thank the insightful comments from two anonymous referees.

\section{Funding}

This paper was financed by National Funds of the FCT - Portuguese Foundation for Science and Technology within the project UIDB/04007/2020.

\section{Disclosure statement}

During the research period, one of the authors accumulated his research position at the university with a nurse position at the hospital group where the study was conducted. Another author had a middle management position at a different private health care group.

\section{References}

Anbori, A., Ghani, S.N., Yadav, H., Daher, A.M., and Su, T.T. (2010), "Patient satisfaction and loyalty to the private hospitals in Sana'a, Yemen", International Journal for Quality in Health Care, Vol. 22 No. 4, pp. 310-315.

Arbel, R., and Greenberg, D. (2016), "Rethinking cost-effectiveness in the era of zero 
healthcare spending growth", International Journal for Equity in Health, Vol. 15, pp. 1-7.

Bearden, W.O., Netemeyer, R.G. and Teel, J.E. (1989), "Measurement of consumer susceptibility to interpersonal influence", Journal of Consumer Research, Vol. 15 No. 4, pp. 473-481.

Buell, R.W., Campbell, D., and Frei, F.X. (2016), "How do customers respond to increased service quality competition?", Manufacturing \& Service Operations Management, Vol. 18 No. 4, pp. 585-607.

Cândido, C.J.F. (2005), "Service quality strategy implementation: A model and the case of the Algarve hotel industry", Total Quality Management \& Business Excellence, Vol. 16 No. 1, pp. 3-14.

Cândido, C.J.F. and Morris, D.S. (2000), "Charting service quality gaps", Total Quality Management, Vol. 11 No. 4/5\&6, pp. S463-S472.

Cândido, C.J.F. and Santos, S.P. (2019), "Implementation obstacles and strategy implementation failure", Baltic Journal of Management, Vol. 14 No. 1, pp. 39-57.

Cândido, C.J.F., Coelho, L.M.S. and Peixinho, R.M.T. (2016), "The financial impact of a withdrawn ISO 9001 Certificate", International Journal of Operations \& Production Management, Vol. 36 No. 1, pp. 23-41.

Cândido, C.J.F., Coelho, L.M.S., and Peixinho, R.M.T. (2019), "Why firms lose their ISO 9001 certification: Evidence from Portugal”, Total Quality Management \& Business Excellence, https://doi.org/10.1080/14783363.2019.1625266.

Chandrasekaran, A., Senot, C., and Boyer, K.K. (2012), "Process management impact on clinical and experiential quality: Managing tensions between safe and patient-centered healthcare", Manufacturing \& Service Operations Management, Vol. 14 No. 4, pp. 548-566.

Chatterjee, D. (1998), Leading Consciously, Routlege, New York.

Chuah, S., Rauschnabel, P., Marimuthu, M., Thurasamy, R. and Nguyen, B. (2017), "Why do satisfied customers defect? A closer look at the simultaneous effects of switching barriers and inducements on customer loyalty", Journal of Service Theory and Practice, Vol. 27 No. 3 , pp. 616-641.

Compton, W.C. (2018), "Self-actualization myths: What did Maslow really say?" Journal of Humanistic Psychology, https://doi.org/10.1177/0022167818761929.

Donabedian A. (1980). Explorations in Quality Assessment and Monitoring: The Definition of Quality and Approaches to Its Assessment, Health Administration Press, Ann Arbor.

Esgarrancho, S. and Cândido, C.J.F. (2020), "Firm preparation for ISO 9001 certification: The case of the hotel industry in Portugal", Total Quality Management \& Business Excellence, Vol. 31 No. 1, pp. 23-42.

Fradera, A. (2018), "Maslow: Putting the record straight", Psychologist, Vol. 31, pp. 14-15.

Genschel, P. (1997), "The dynamics of inertia: Institutional persistence and change in telecommunications and health care", Governance - An International Journal of Policy and Administration, Vol. 10 No. 1, pp. 43-66.

Gray, D.M., D’Alessandro, S., Johnson, L.W. and Carter, L. (2017), "Inertia in services: Causes and consequences for switching”, Journal of Services Marketing, Vol. 31 No. 6, pp. 485498.

Gu, R., Oh, L.-B., and Wang, K. (2016), "Developing user loyalty for social networking sites: A relational perspective", Journal of Electronic Commerce Research, Vol. 7 No. 1, pp. 121.

Hair, J.F., Hult, G.T.M., Ringle, C.M., and Sarstedt, M. (2014), A Primer on Partial Least Squares Structural Equation Modeling (PLS-SEM), Sage, London.

Han, H., and Hyun, S.S. (2015), "Customer retention in the medical tourism industry: Impact of quality, satisfaction, trust and price reasonableness", Tourism Management, Vol. 46, pp. 20-29. 
Han, H. Kim, Y. and Kim, E.-K. (2011), "Cognitive, affective, conative, and action loyalty: Testing the impact of inertia", International Journal of Hospitality Management, Vol. 30, pp. 108-1019.

Han, H., Lee, K.-S., Chua, B.-L., Lee, S. and Kim, W. (2019), "Role of airline food quality, price reasonableness, image, satisfaction, and attachment in building re-flying intention", International Journal of Hospitality Management, Vol. 80, pp. 91-100.

Hornsey, M. and Jetten, J. (2005), "Loyalty without conformity: Tailoring self-perception as a mean of balancing belonging and differentiation", Self and Identity, Vol. 4 No. 1, pp. 81-95.

Hussain, K., Jing, F., Junaid, M., Bukhari, F.A.S., and Shi, H. (2019), "The dynamic outcomes of service quality: A longitudinal investigation", Journal of Service Theory and Practice, Vol. 29 No. 4, pp. 513-536.

Jin, N.P., Line, N.D. and Merkebu, J. (2016), "The effects of image and price fairness: A consideration of delight and loyalty in the waterpark industry", International Journal of Contemporary Hospitality Management, Vol. 28 No. 9, pp. 1895-1914.

Johnson, M, Gustafsson, A. Andreassen, T., Lervik, L. and Cha, J. (2001), "The evolution and future of national customer satisfaction index models", Journal of Economic Psychology, Vol. 22 No. 2, pp. 217-245.

Juga, J., Juntunen, J., and Grant, D.B. (2010), "Service quality and its relation to satisfaction and loyalty in logistics outsourcing relationships", Managing Service Quality, Vol. 20 No. 6, pp. 496-510.

Kerschbamer, R., Sutter, M., and Dulleck, U. (2017), "How social preferences shape incentives in (experimental) markets for credence goods", The Economic journal, Vol. 127 No. 600, pp. 393-416.

Kim, B. and Kang, M. (2016), "How user loyalty and nonconscious inertia influence the continued use of mobile communications platforms", International Journal of Mobile Communications, Vol. 14 No. 4, pp. 387-410.

Kotler, P., Armstrong, G., Harris, L.C. and Piercy, N. (2017), Principles of Marketing, Pearson, Harlow.

Kotler, P. and Lee, N. (2007), Marketing in the Public Sector: A Roadmap for Improved Performance, Prentice Hall, Upper Saddle River.

Lai, L.-H., Liu, C.-T., Lin, J.-.T. (2011), "The moderating effects of switching costs and inertia on the customer satisfaction-retention link: Auto liability insurance service in Taiwan", Insurance Markets and Companies, Vol. 2 No. 1, pp. 69-78.

Lam, S.Y., Shankar, V., Erramilli, M.K., and Murthy, B. (2004), "Customer value, satisfaction, loyalty, and switching costs: An illustration from a business-to-business service context", Journal of the Academy of Marketing Science, Vol. 32 No. 3, pp. 293-311.

Lee, R., Klobas, J. Tezinde, T. and Murphy, J. (2010), "The underlying social identities of a nation's brand", International Marketing Review, Vol. 27 No. 4, pp. 450-465.

Li, C.-Y. (2015), "Switching barriers and customer retention: Why customers dissatisfied with online service recovery remain loyal", Journal of Service Theory and Practice, Vol. 25 No. 4, pp. 370-393.

Lin, G.T.R. and Sun, C. (2009), "Factors influencing satisfaction and loyalty in online shopping: An integrated model", Online Information Review, Vol. 33 No. 3, pp. 458-475.

Liu-Thompkins, Y. and Tam, L. (2013), "Not all repeat customers are the same: Designing effective cross-selling promotion on the basis of attitudinal loyalty and habit", Journal of Marketing, Vol. 77 No. 5, pp. 21-36.

Lobo, A., Duarte, P., Carvalho, A., Rodrigues, V., Monteiro, M.J. and Alves, H. (2014), "The association of equity, accessibility, and price with primary healthcare user's satisfaction", Western Journal of Nursing Research, Vol. 36 No. 2, pp. 191-208.

Lucia-Palacios, L., Pérez-López, R. and Polo-Redondo, Y. (2016), "Enemies of cloud services 
usage: Inertia and switching costs", Service Business, Vol. 10 No. 2, pp. 447-467.

Marimon, F., Heras, I., and Casadesús, M. (2009), "ISO 9000 and ISO 14000 standards: A projection model for the decline phase", Total Quality Management, Vol. 20 No. 1, pp. 121.

Martín-Consuegra, D., Molina, A., and Esteban, À. (2007), “An integrated model of price, satisfaction and loyalty: An empirical analysis in service sector", Journal of Product \& Brand Management, Vol. 16 No. 7, pp. 459-468.

Martínez-Caro, E., Cegarra-Navarro, J.G., and Solano-Lorente, M. (2013), "Understanding patient e-loyalty toward online health care services", Health Care Management Review, Vol. 38 No. 1, pp. 61-70.

Maslow, A.H. (1970), Motivation and Personality, Harper \& Row, New York.

Mohd-Any, A.A., Mutum, D.S., Ghazali, E.M. and Mohamed-Zulkifli, L. (2019), "To fly or not to fly? An empirical study of trust, post-recovery satisfaction and loyalty of Malaysia Airlines passengers", Journal of Service Theory and Practice, Vol. 29 No. 5/6, pp. 661-690.

Moliner, M. (2009), "Loyalty, perceived value and relationship quality in healthcare services", Journal of Services Management, Vol. 20 No. 1, pp. 76-97.

Nitzan, I. and Libai, B. (2011), "Social effects on customer retention", Journal of Marketing, Vol. 75 No. 6, pp. 24-38.

Ofori, K.S., Boakye, K. and Narteh, B. (2018), "Factors influencing consumer loyalty towards 3G mobile data service providers", Total Quality Management \& Business Excellence, Vol. 29 No. 5-6, pp. 580-598.

Oliver, R. (1980), "A cognitive model of the antecedents and consequences of satisfaction decisions", Journal of Marketing Research, Vol. 17 No. 4, 460-469.

Oliver, R. (1999), "Whence consumer loyalty”, Journal of Marketing, Vol. 63 No. 4, pp. 3344.

Olsen, S.O., Tudoran, A.A., Brunsø, K. and Verbeke, W. (2013), "Extending the prevalent consumer loyalty modelling: the role of habit strength", European Journal of Marketing, Vol. 47 No. 1/2, pp. 303-323.

Podsakoff, P., MacKenzie, S., Lee, J., and Podsakoff, N. (2003), "Common method biases in behavioral research", Journal of Applied Psychology, Vol. 88 No. 5, pp. 879-903.

Pollack, B.L. (2017), "Effects of exit barriers on word-of-mouth activities", Journal of Services Marketing, Vol. 31 No. 6, pp. 512-526.

Ranaweera, C. and Neely, A. (2003), "Some moderating effects on the service quality-customer retention link", International Journal of Operations \& Production Management, Vol. 23 No. 2, pp. 230-248.

Ringle, C.M., Wende, S., and Will, A. (2005), SmartPLS 2.0 [Computer software], retrieved from www.smartpls.com.

Ruiz-Mafe, C., Tronch, J., Sanz-Blas, S. (2016), "The role of emotions and social influences on consumer loyalty towards online travel communities", Journal of Service Theory and Practice, Vol. 26 No. 5, pp. 534-558.

Saleem, M.A., Zahra, S., Ahmad, R. and Ismail, H. (2016), "Predictors of customer loyalty in the Pakistani banking industry: A moderated-mediation study", International Marketing Review, Vol. 27 No. 4, pp. 450-465.

Taormina, R.J. and Gao, J.H. (2013), "Maslow and the motivation hierarchy: Measuring satisfaction of the needs", American Journal of Psychology, Vol. 126 No. 2, pp. 155-177.

Tay, L. and Diener, E. (2011), "Needs and subjective well-being around the world", Journal of Personality and Social Psychology, Vol. 101 No. 2, pp. 354-365.

Teas, R. (1994), "Expectations as a comparison standard in measuring service quality: An assessment of a reassessment", Journal of Marketing, Vol. 58 No. 1, pp. 132-139.

Teng, C. (2018), "Managing gamer relationships to enhance online gamer loyalty: The 
perspectives of social capital theory and self-perception theory", Computers in Human Behavior, Vol. 79, pp. 59-67.

Tinoco, P.C.R., Cândido, C.J.F. and Feliciano, I.M.P.L. (2017), "A importância da avaliação da qualidade percebida em radiologia e o impacto dos fatores sociodemográficos num hospital público português", Portuguese Journal of Public Health, Vol. 35 No. 3, pp. $202-$ 213.

Toker-Yildiz. K., Trivedi, M., Choi, J. and Chang, S.R. (2017), "Social interactions and monetary incentives in driving consumer repeat behavior", Journal of Marketing Research, Vol. 54 No. 3, pp. 364-380.

Tsai, H.-T., Pai, P. (2012), "Positive and negative aspects of online community cultivation: Implications for online stores' relationship management", Information \& Management, Vol. 49 No. 2, pp. 111-117.

Tsai, H., Hsu, C.H.C. and Lee, L.Y. (2017), "A casino-induced satisfaction of needs: scale development and its relationship with casino customer loyalty", Journal of Travel and Tourism Marketing, Vol. 34 No. 7, pp. 986-1000.

Wang, X. and Zhang, Q. (2018), "Does online service failure matter to offline customer loyalty in the integrated multi-channel context? The moderating effect of brand strength", Journal of Service Theory and Practice, Vol. 28 No. 6, pp. 774-806.

Wu, C. (2011b), "The impact of hospital brand image on service quality, patient satisfaction and loyalty", African Journal of Business Management, Vol. 5 No. 12, pp. 4873-4882.

Wu, L. (2011a), "Satisfaction, inertia, and customer loyalty in the varying levels of the zone of tolerance and alternative attractiveness", Journal of Services Marketing, Vol. 25 No. 5, pp. 310-322.

Zalenski, R.J. and Raspa, R. (2006), "Maslow's hierarchy of needs: A framework for achieving human potential in hospice", Journal of Palliative Medicine, Vol. 9 No. 5, pp. 1120-1127.

Zeithaml, V., Berry, L. and Parasuraman, A. (1996), "The behavioral consequences of service quality", Journal of Marketing, Vol. 60 No. 2, pp. 31-46.

Zhou, W., Wan, Q., Liu, C., Feng, X., and Shang, S. (2017), "Determinants of patient loyalty to healthcare providers: An integrative review", International Journal for Quality in Health Care, Vol. 29 No. 4, pp. 442-449. 